\title{
PEMANFAATAN FITUR PROOFING, AUTO CORRECT, DAN AUTO FORMAT PADA APLIKASI OFFICE DALAM MENINGKATKAN PELAYANAN PRIMA PADA LEMBAGA PELATIHAN KOMPUTER
}

\author{
Wahyu Kurnia Dewanto'), Moh. Munih Dian Widianta'2) \\ Jurusan Teknologi Informasi, Politeknik Negeri Jember \\ 1)wahyukurniadewanto@yahoo.com; \\ 2)munihdian@gmail.com
}

\begin{abstract}
ABSTRAK
Lembaga Metronet Mandiri di Ambulu ini adalah sebuah usaha kursus komputer dan jasa pengetikan bagi masyarakat dan siswa sekolah sekitar. Dalam operasionalnya memiliki beberapa masalah antara lain: (1) Bagaimana meningkatkan pelayanan jasa pengetikan dan cetak dokumen; (2) Bagaimana meningkatkan kemampuan karyawan/instruktur dalam memaksimalkan fitur proofing pada aplikasi komputer sehingga dapat memeriksa ejaan yang baik dan benar sesuai dengan EYD yang telah ditetapkan.

Melalui kegiatan pengabdian masyarakat pada lembaga ini diharapkan dapat: (1) Meningkatnya efektivitas kerja para instruktur dan karyawan; (2) Memberikan kepuasan karena dilayani dengan cepat dan prima; (3) Memaksimalkan fitur yang ada pada aplikasi Office; (4) Meningkatkan pendapatan lembaga ini.

Luaran dari kegiatan PPM ini adalah: (1) Membuat sebuah file add on yang kemudian ditanam pada aplikasi Office yang ada pada komputer; (2) Membuat beberapa file (dictionary kosa kata Bahasa Indonesia) yang dibutuhkan oleh aplikasi Office dalam memaksimalkan fasilitas proofing sehingga dapat dengan cepat dan otomatis akan memeriksa kosa kata sehingga proses edit dokumen dapat dilakukan dengan lebih cepat (3) Pemanfaatan fitur autocorrect dan autoformat sebagai media untuk proses editing dokumen secara cepat dan tepat.

Metode yang dilakukan antara lain: (1) Survei lapangan; (2) Pembuatan Add On Office; (3) Uji Coba dan Instalasi serta penyerahan; (4) Memantau perkembangan dan evaluasi. Hasilnya adalah diketahui peran mitra secara aktif mengikuti dengan seksama petunjuk penggunaan fitur yang ada pada aplikasi Office tersebut yang setelah diserahterimakan oleh tim pelaksanaan program Pengabdian Kepada Masyarakat kepada mitra. Kemudian peserta atau mitra pengabdian ini mengoperasikan add on tersebut di tempat kerja.
\end{abstract}

Keywords -- Autocorrect, Custom Dictionaries; Proofing

\section{PENDAHULUAN}

Lembaga pelatihan dan pengembangan profesi Metronet Mandiri yang berada di Kecamatan Ambulu, Kabupaten Jember ini adalah sebuah lembaga yang bergerak di bidang pelatihan atau kursus komputer. Lembaga ini di samping sebagai tempat kursus komputer, namun juga terdapat pelayanan pengetikan dan rental komputer/internet. Dalam kesehariannya khususnya pada pelayanan jasa pengetikan dan jasa cetak dokumen dapat menerima omzet hingga ratusan ribu rupiah dari beberapa pelanggan yang datang.

Lembaga ini memiliki 5 orang karyawan yang bekerja secara shift dan disesuaikan dengan bidangnya. Karena memiliki karyawan yang terbatas di mana khususnya jasa pengetikan dibuka dari pagi jam 6.00 hingga jam 22.00 malam dengan jumlah pengguna tidak sedikit, maka pelayanannya dirasa sangat lambat. Jumlah komputer yang digunakan untuk bagian administrasi juga hanya dua buah komputer, sementara komputer yang digunakan untuk rental pengetikan dan jasa cetak dokumen sebanyak 6 buah.
Pada umumnya masyarakat yang menggunakan jasa pengetikan di sini adalah dalam pembuatan artikel, skripsi, laporan kegiatan, pembuatan undangan, tugas-tugas rangkuman dari sekolah khususnya siswa SMP dan SMA yang ada di sekitar wilayah kecamatan Ambulu, Wuluhan dan Temporejo.

Dalam melakukan pelayanan terhadap masyarakat yang menggunakan jasa lembaga ini, khususnya pada usaha pengetikan dan cetak dokumen, dua orang tenaga administrasi yang masih lulusan SMA ini menggunakan komputer yang telah diinstal aplikasi Office yang masih standar. Artinya, aplikasi komputer yang ada belum dapat dimanfaatkan secara maksimal karena belum adanya library atau file Add on yang dapat dimanfaatkan untuk meningkatkan kinerja komputer.

\section{A. Permasalahan Mitra}

Berdasarkan latar belakang masalah di atas, maka dapat dirumuskan beberapa masalah sebagai berikut:

1. Bagaimana meningkatkan pelayanan jasa pengetikan dan cetak dokumen kepada 
masyarakat yang menggunakan jasa lembaga ini.

2. Bagaimana meningkatkan kemampuan karyawan/instruktur dalam kinerjanya memaksimalkan fitur-fiture yang dimiliki oleh aplikasi Office yang sudah tertanam dalam komputer lembaga tersebut.

3. Bagaimana fitur-fitur yang ada pada aplikasi komputer dapat secara maksimal dimanfaatkan dan diberdayakan dalam meningkatkan pelayanan jasa pengetikan.

4. Bagaimana fasilitas proofing pada aplikasi komputer dapat memeriksa ejaan atau Kosta kata bahasa Indonesia yang baik dan benar sesuai dengan EYD yang telah ditetapkan.

5. Belum adanya file add on untuk fasilitas autocorrect dan auto format maka mustahil, aplikasi Office yang ada dapat dimanfaatkan secara maksimal, untuk itu tim pengabdi masyarakat akan memberikan atau menambahkan file add on tersebut pada mitra ini.

\section{B. Manfaat}

Setelah dilakukan Pengabdian kepada Masyarakat ini diharapkan lembaga pelatihan komputer Metronet, Ambulu akan memperoleh manfaat, antara lain:

1. Meningkatnya efektivitas kerja para instruktur dalam melakukan pelayanan jasa pengetikan dan pemeriksaan dokumen serta cetak dokumen.

2. Memberikan kepuasan kepada masyarakat yang memanfaatkan jasa lembaga ini dalam pengetikan dan cetak dokumen karena dilayani dengan cepat dan prima.

3. Memaksimalkan fitur yang ada pada aplikasi Office untuk secara optimal dapat dimanfaatkan oleh karyawan dalam melakukan pelayanan kepada pelanggan.

4. Meningkatkan pendapatan lembaga ini melalui meningkatnya pelayanan khususnya pada jasa pengetikan.

\section{TARGET DAN LUARAN}

\section{A. Target}

Sesuai dengan latar belakang dan perumusan masalah yang telah diuraikan sebelumnya, maka target Pengabdian kepada Masyarakat yang dilaksanakan ini bagi lembaga Pelatihan Komputer dan Pengembangan Profesi Metronet yang ada di Kecamatan Ambulu Kabupaten Jember, antara lain:

1. Meningkatkan kinerja karyawan dalam pelayanan jasa pengetikan/keriting dan cetak dokumen.
2. Memberikan kepuasan kepada masyarakat yang memanfaatkan jasa lembaga ini dalam pengetikan dan cetak dokumen karena dilayani dengan cepat dan prima.

3. Memaksimalkan fitur yang ada pada aplikasi Office untuk secara optimal dapat dimanfaatkan oleh karyawan dalam melakukan pelayanan kepada pelanggan.

4. Meningkatkan pendapatan lembaga ini melalui meningkatnya pelayanan khususnya pada jasa pengetikan.

5. Bukan hanya cepat dalam pelayanan, namun juga mengurangi kesalahketikan/ kosa kata yang salah pada dokumen yang diketik dan dicetak oleh karyawan lembaga ini karena adanya fitur proofing pada aplikasi komputer setelah keterampilan karyawan bertambah melalui kegiatan pengabdian masyarakat.

\section{B. Luaran}

Luaran dari kegiatan Program Pengabdian Kepada Masyarakat adalah:

1. Membuat sebuah file add on yang kemudian ditanam pada aplikasi Office yang ada pada komputer lembaga ini.

2. Membuat beberapa file (dictionary kosa kata Bahasa Indonesia) yang dibutuhkan oleh aplikasi Office dalam memaksimalkan fasilitas proofing sehingga dapat dengan cepat dan otomatis akan memeriksa kosa kata sehingga proses edit dokumen dapat dilakukan dengan lebih cepat.

3. Penerapan fitur proofing pada aplikasi Office yang kebanyakan banyak usir atau pengguna komputer tidak tahu.

4. Pemanfaatan fitur autocorrect dan autoformat sebagai media untuk proses keriting dokumen secara cepat dan tepat.

\section{METODE PELAKSANAAN}

\section{A. Rencana Kegiatan}

Dari sekian banyaknya permasalahan mitra Program Pengabdian Kepada Masyarakat yang telah diuraikan sebelumnya, maka metode pendekatan yang ditawarkan untuk dicarikan solusinya adalah dengan kesepakatan bersama antara tim Pelaksana Program Pengabdian Kepada Masyarakat Politeknik Negeri Jember adalah melalui 4 tahap kegiatan, yaitu tahap studi pustaka, survei lapangan, desain media, tahap penyerahan aplikasi kepada mitra, memberikan pelatihan dan pengarahan di lapangan, serta tahap memantau perkembangan. Tahapan- 
tahapan tersebut dapat digambarkan sebagai berikut:

1. Survei lapangan

Tahapan ini adalah mencari data dan informasi di lapangan yang diperlukan seperti versi Sistem Operasi dan versi Office untuk pengerjaan pembuatan Add on. Tahap ini meliputi metode wawancara dan observasi.

2. Pembuatan Add On Office.

Tahap ini adalah pembuatan Add on untuk auto correct dan auto format serta library proofing pada aplikasi Office.

3. Uji Coba dan Instalasi serta penyerahan File library dan file add on untuk Office diujicobakan dulu apakah sudah dapat berjalan sesuai dengan yang derencanakan, kemudian tahap penyerahan alat berupa dan instalasi kepada mitra Pengabdian Kepada Masyarakat dan memberikan petunjuk cara menggunakannya.

4. Memantau perkembangan

Tahap melihat perkembangan kinerja pelayanan karyawan pada lembaga mitra pengabdian kepada masyarakat tersebut.

\section{B. Pelaksanaan Program Dan Peran Mitra}

1. Tim pelaksana pengabdian melalui program Pengabdian Kepada Masyarakat ini adalah membuat file Add on Office serta membuat file dictionary sebagai library untuk fitur proofing pada aplikasi Office.

2. Tim pelaksana Pengabdian Kepada Masyarakat dalam membuat file add on ini melibatkan teknisi dan mahasiswa teknologi informasi.

3. Peran mitra secara aktif mengikuti dengan seksama petunjuk penggunaan fitur yang ada pada aplikasi Office tersebut yang setelah diserahterimakan oleh tim pelaksanaan program Pengabdian Kepada Masyarakat kepada mitra.

4. Kemudian peserta atau mitra pengabdian ini mengoperasikan add on tersebut di tempat kerja yaitu lembaga ini.

Evaluasi dan pendampingan dilakukan setelah kegiatan pelatihan dilaksanakan. Peran mitra dalam pelaksanaan program ke depan adalah secara aktif dan terencana untuk dapat menggunakan aplikasi ini.

Tanya jawab dilakukan dengan tujuan untuk memberikan kesempatan kepada karyawan/instruktur agar dapat mengetahui dengan lebih jelas mengenai hal-hal yang belum dipahaminya tentang fitur-fitur tersebut. Kegiatan ini bertujuan untuk melatih karyawan lebih tanggap dan cepat serta tepat dalam mengedit atau mengetik dokumen yang menjadi pekerjaan mereka.

\section{HASIL YANG DICAPAI}

\section{A. Survei lapangan}

Tahapan ini adalah mencari data dan informasi di lapangan yang diperlukan seperti versi Sistem Operasi dan versi Office untuk pengerjaan pembuatan Add on. Tahap ini meliputi metode wawancara dan observasi dengan komunikasi melalui telepon. Di dapat bahwa komputer yang tersedia di lembaga komputer ini terdiri dari:

Tabel 1. Data Komputer Lembaga Metronet

\begin{tabular}{|c|l|c|c|c|}
\hline No & Komputer & Processor & OS & Office \\
\hline 1 & Admin 1 & $\begin{array}{c}\text { AMD } \\
\text { AM3 }\end{array}$ & $\begin{array}{c}\text { Win } \\
8 / 64 \mathrm{bit}\end{array}$ & $\begin{array}{c}\text { Ms. Office } \\
2012\end{array}$ \\
\hline 2 & Admin 1 & $\begin{array}{c}\text { Intel LG } \\
775\end{array}$ & $\begin{array}{c}\text { Win XP/ } \\
32 \mathrm{bit}\end{array}$ & $\begin{array}{c}\text { Ms. Office } \\
2007\end{array}$ \\
\hline 3 & PC 1 & AMD FM2 & $\begin{array}{c}\text { Win } \\
8 / 64 \mathrm{bit}\end{array}$ & $\begin{array}{c}\text { Ms. Office } \\
2010\end{array}$ \\
\hline 4 & PC 2 & AMD FM1 & $\begin{array}{c}\text { Win } \\
8 / 64 \mathrm{bit}\end{array}$ & $\begin{array}{c}\text { Ms. Office } \\
2010\end{array}$ \\
\hline 5 & PC 3 & AMD FM2 & $\begin{array}{c}\text { Win } \\
8 / 64 \mathrm{bit}\end{array}$ & $\begin{array}{c}\text { Ms. Office } \\
2010\end{array}$ \\
\hline 6 & PC 4 & $\begin{array}{c}\text { AMD } \\
\text { AM3 }\end{array}$ & $\begin{array}{c}\text { Win } \\
8 / 64 \mathrm{bit}\end{array}$ & $\begin{array}{c}\text { Ms. Office } \\
2010\end{array}$ \\
\hline 7 & PC 5 & $\begin{array}{c}\text { AMD } \\
\text { AM3 }\end{array}$ & $\begin{array}{c}\text { Win } \\
8 / 64 \mathrm{bit}\end{array}$ & $\begin{array}{c}\text { Ms. Office } \\
2010\end{array}$ \\
\hline 8 & PC 6 & $\begin{array}{c}\text { AMD } \\
\text { AM3 }\end{array}$ & $\begin{array}{c}\text { Win } \\
8 / 64 \mathrm{bit}\end{array}$ & $\begin{array}{c}\text { Ms. Office } \\
2010\end{array}$ \\
\hline
\end{tabular}

Dari data di atas, bahwa komputer yang ada memiliki spesifikasi yang berbeda secara hardware yang tentu saja mempengaruhi kecepatan kerja dari masing-masing komputer tersebut. Operating System yang tertanam pada 7 unit komputer sudah menggunakan Windows 8, kecuali satu unit yang masih menggunakan windows XP karena spesifikasi komputernya termasuk lambat. Adapun versi Microsoft Office yang digunakan juga hampir semuanya menggunakan Office versi 2010.

\section{B. Pembuatan Add On Office.}

Tahap ini adalah pembuatan Add on untuk auto correct dan auto format serta library proofing pada aplikasi Office.

1. Autocorrect

Teknik pembuatan autocorrect sebebenarnya dengan memanfaatkan fasilitas autocorrect yang sudah tersedia dalam program Microsoft Office, namun jarang sekali para pengguna yang tahu fasilitas ini. 


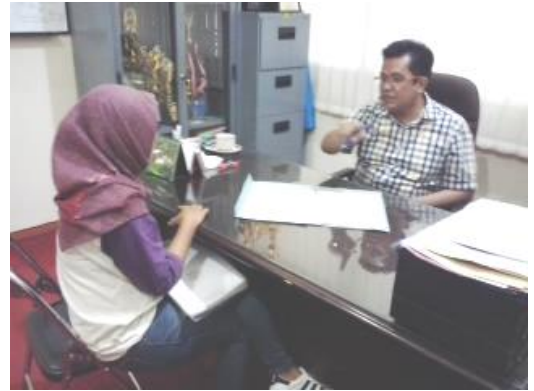

Foto 1. Diskusikan Fasilitas Autocorrect

Fasilitas autocorrect dalam Microsoft Office dapat ditambahkan melalui sebuah menu yang dipanggil melalui Short cut Alt+T dan A, sehingga muncul kotak dialog sebagai berikut:

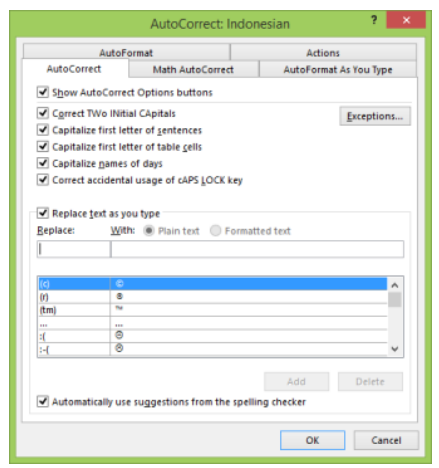

Gambar 1. Auto Correct pada Ms. Office

Selanjutnya pengisian dilakukan oleh teknisi dan mahasiswa hingga beberapa kata yang direncanakan untuk dimasukkan ke aplikasi ini selesai. Kegunaan dari autocorrect sebenarnya adalah untuk memeriksa secara otomatis katakata yang salah ketik kemudian diperbaiki secara otomatis pula. Namun akhirnya dapat dikembangkan untuk metode ketik cepat. Sehingga dalam melakukan ketikan kata-kata tertentu tidak perlu mengetik semua huruf, melainkan cukup dengan inisial atau huruf kunci yang selanjutnya dibiarkan program akan memperbaikinya. Sebagai contoh:

Tabel 2. Fasilitas Autocorrect Yang Sudah Tersedia

\begin{tabular}{|c|l|l|}
\hline No & \multicolumn{1}{|c|}{ Key } & \multicolumn{1}{c|}{ Hasil } \\
\hline 1 & $1 / 2$ & $1 / 2$ \\
\hline 2 & $3 / 4$ & $3 / 4$ \\
\hline 3 & $(\mathrm{c})$ & $\mathrm{C}$ \\
\hline 4 & $(\mathrm{R})$ & $\mathbb{B}$ \\
\hline 5 & $>>$ & $\gg$ \\
\hline 6 & $==>$ & $\rightarrow$ \\
\hline 7 & $-->$ & $\rightarrow$ \\
\hline 8 & $:)$ & ( \\
\hline 9 & abbout & about \\
\hline 10 & Accomodate & Accommodate \\
\hline
\end{tabular}

Dan masih banyak lagi kata-kata dalam bahasa Inggris yang mampu diperbaiki secara otomatis oleh program. Namun untuk kata-kata dalam bahasa Indonesia karena belum ada haruslah ditambahkan satu demi satu dalam aplikasi ini.

Tabel 3. Fasilitas Autocorrect Yang Sudah Ditambahkan

\begin{tabular}{|c|l|l|}
\hline No & \multicolumn{1}{|c|}{ Key } & \multicolumn{1}{c|}{ Hasil } \\
\hline 1 & $\mathrm{ttg}$ & tentang \\
\hline 2 & $\mathrm{mrp}$ & merupakan \\
\hline 3 & $\mathrm{yg}$ & yang \\
\hline 4 & $\mathrm{dg}$ & dengan \\
\hline 5 & ket & keterangan \\
\hline 6 & dll & dan lain-lain \\
\hline
\end{tabular}

Dan masih banyak lagi kata-kata dalam bahasa Indonesia yang dapat ditambahkan ke dalam fasilitas autocorrect Ms. Office sehingga dapat mempercepat dan mempersingkat waktu dan tenaga dalam melakukan pekerjaan pengetikan dokumen. Sehingga diharapkan dalam pelayanan rental maupun jasa pengetikan pada metronet Ambulu dapat lebih tepat waktu dan menambah pendapatan pada jasa ini.

Adapun pengisian kata-kata yang dilakukan oleh teknisi maupun mahasiswa dan karyawan yang ada melalui kotak dialog sebagaimana pada gambar 2 berikut:

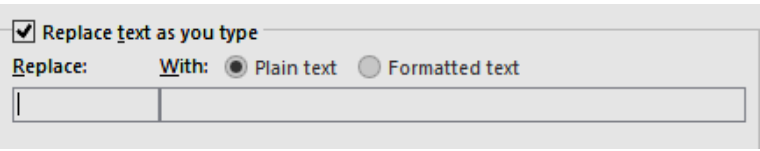

Gambar 2. Entri Autocorrect

Pada bagian replace adalah bagian Key atau huruf yang akan dijadikan kunci kata-kata. Sedangkan sebelah kanan yaitu With, berisi kata yang menjadi hasilnya. Sebagaimana yang ada di tabel 2 adalah contoh beberapa kunci dan hasil, seperti "yg" akan menghasilkan kata "yang", "dg" akan menghasilkan kata "dengan", dan sebagainya.

\section{Proofing}

Adalah fasilitas yang disediakan oleh Microsoft Office untuk memeriksa kebenaran ejaan kosa kata baik dalam bahasa Inggris maupun bahasa Indonesia. Setiap kosa kata yang dianggap salah ketik atau yang belum ada pada library akan ditandai dengan garis bawah warna merah pada kosa kata tersebut. Para pengguna (user) Microsoft Office banyak yang belum tahu 
fasilitas ini, sehingga sengaja atau tidak sengaja dibiarkan yang akibatnya tidak bisa mengetahui mana yang harus diperbaiki karena salah ketikan. Fasilitas ini sangat berguna karena dapat meningkatkan kualitas ketikan dari sisi EYD Bahasa Indonesia.

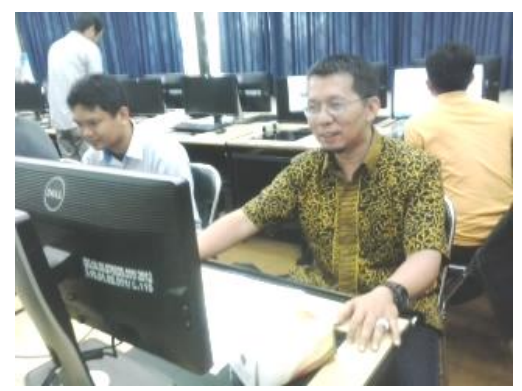

Foto 2. Penambahan Proofing

Memanfaatkan fasilitas proofing dengan Menu Word options, kemudian pilih bagian proofing seperti gambar 3 berikut.

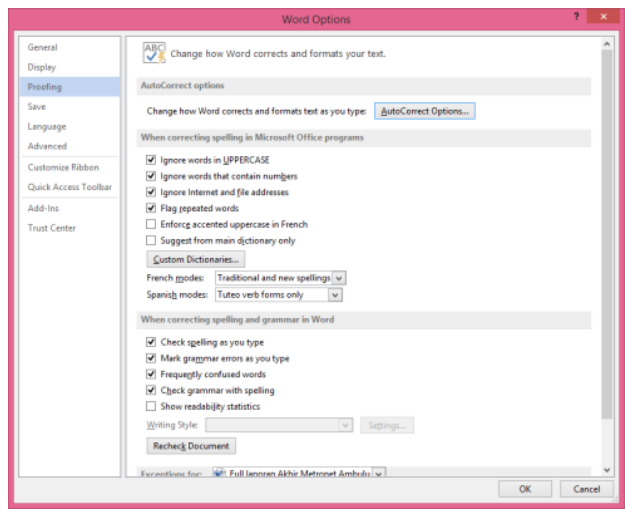

Gambar 3. Option

Selanjutnya adalah klik "Custom Dictionaries" sebagaimana gambar 4 berikut.

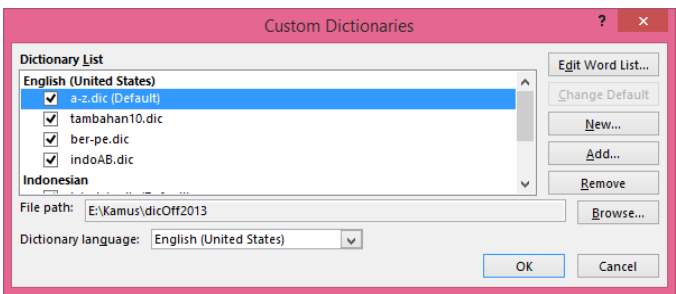

Gambar 4. Custom Dictionaries

Selanjutnya adalah menambahkan file *.dic yang sudah disediakan oleh tim pengabdian masyarakat ke dalam Custom dictionaries tersebut. Terdapat lebih dari 6 file *.dic yang masing-masing memiliki data kosa kata dalam bahasa Indonesia.

\section{Uji Coba dan Instalasi serta penyerahan}

File library dan file add on untuk Office diujicobakan dulu apakah sudah dapat berjalan sesuai dengan yang derencanakan, kemudian tahap penyerahan alat berupa dan instalasi kepada mitra Pengabdian Kepada Masyarakat dan memberikan petunjuk cara menggunakannya. File-file Add on tersebut seperti *.dic dan *.acl dikirimkan melalui internet e-mail maupun media sosial facebook. Namun demikian beberapa pertemuan diadakan di kampus untuk menerima pengarahan dan penjelasan cara menggunakan file-file tersebut.

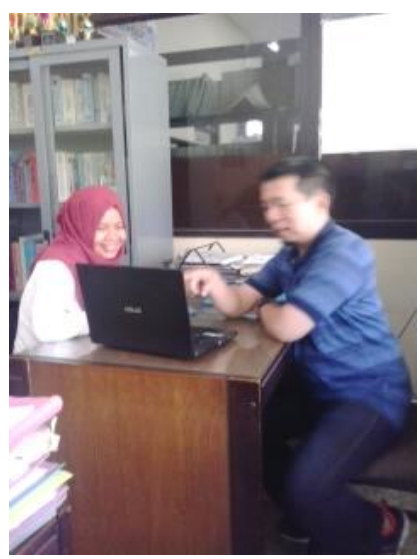

Foto 3. Memberikan Pengarahan

\section{Memantau perkembangan}

Tahap melihat perkembangan kinerja pelayanan karyawan pada lembaga mitra pengabdian kepada masyarakat tersebut. Beberapa kegiatan pemantauan dilakukan melalui komunikasi WA maupun telepon untuk menanyakan kendala dan hambatan penggunaan file add on autocorrect maupun file dictionaries.

\section{KEBERLANJUTAN PROGRAM}

Kegiatan pengabdian pada masyarakat telah selesai dan keberlanjutan program adalah mengimplentasikan fasilitas yang sebenarnya sudah tersedia dalam program Ms. Office ini secara maksimal. Beberapa komputer yang ada di lembaga ini semua perlu dimaksimalkan dengan cara yang sama pada komputer amin/master. Sehingga semua komputer yang direntalkan dapat memiliki kecepatan dan keunggulan yang sama.

Kegiatan ini bagi tim pengabdian masyarakat akan terus terjalin komunikasi dan kerjasama dengan lembaga metronet Ambulu. Sehingga 
apabila diperlukan kegiatan pelatihan lanjutan bagi karyawan maupun kegiatan lainnya untuk meningkatkan kualitas layanan lembaga, terutama yang memanfaatkan aplikasi komputer, maka tim pengabdian akan memfasilitasi dalam bentuk kegiatan pengabdian lain sesuai kebutuhan.

\section{KESIMPULAN DAN SARAN}

\section{A. Kesimpulan}

Hasil yang dicapai dari kegiatan pengabdian pada masyarakat adalah sebagai berikut:

a. Masih banyaknya penggunaan aplikasi Microsoft Office terutama Ms. Word yang belum memanfaatkan fasilitas autocorrect.

b. Setelah diadakan kegiatan pengabdian masyarakat melalui program pemanfaatan fasilitas autocorrect pada lembaga metronet Ambulu, maka waktu yang dibutuhkan oleh karyawan dalam melayani jasa pengetikan para pelanggan menjadi lebih cepat.

c. Demikian juga untuk hasil pengetikan dalam hal kesalahan ketikan dapat dikurangi atau diminimalisir karena memanfaatkan fasilitas Custom dictionaries sehingga kesalahan ketik dapat segera dikoreksi.

\section{B. Saran}

Berdasarkan hasil yang diperoleh dalam kegiatan pengabdian pada masyarakat ini beberapa saran yang bisa disampaikan bahwa untuk lebih efektif lagi kegiatan pengabdian masyarakat ini perlu lebih intens memberikan pelatihan terutama kepada karyawan lembaga metronet Ambulu. OS yang tertanam pada komputer hendaknya diseragamkan karena masih adanya Windows versi lama yaitu Windows XP yang tentu saja berbeda dalam langkah-langkah pengimplementasian fasilitas ini.

\section{DAFTAR PUSTAKA}

[1] Anisyah, 2000. Konsep Dasar Aplikasi dan Pemrograman Java. Yogyakarta: Penerbit Andi

[2] Ben M. Schorr. 2007. The Lawyer's Guide do Microsoft Word 2007. http://ababooks.org

[3] Davis, Guy Hart dan Ty Anderson. 2010. Beginning Microsoft Word 2010. USA: Appress.

[4] Jogiyanto, H. 2005. Analisis dan Desain Sistem Informasi Edisi III. Yogyakarta: Andi.

[5] Habraken, Joe. 2002. 10 Minutes Guide do Microsoft Word 2002. USA: Que.

[6] Pinard, Morisson. 2011. Microsoft Word Complete. Boston: Course Technology

[7] Purnomo, Catur Hadi, 2007. 117 Tip dan Trik Microsoft Office 2007. Jakarta: Mediakita

[8] Kurnaiwan, Yahya. 2010. Belajar Sendiri Microsoft Office Word 2010. Jakarta: Elex Media Komputindo

[9] Seft Learning, 2014. Cara Ketik dan Edit Kata dengan Fungsi Autocorrect pada Microsoft Office Word.

http://www.rumusexcellengkap.com/2014/01/ mengedit-kata-dengan-autocorrect-dalam.html

[10] Supriyanto, D. dan Agustina, R.2012. Pemrograman Aplikasi Android. Jakarta: PT. Buku Seru 